\title{
Political Behavior Typology of Students As First-Time Voters
}

\author{
Adela Danaj \\ European University of Tirana \\ adeladanaj@hotmail.com \\ Roland Lami \\ European University of Tirana \\ roland.lami@uet.edu.al
}

\begin{abstract}
The study of political behavior is a fundamental issue for the analysis of democratic systems, since it derives the choice of government. This is why many researchers have paid a particular attention to the behavior of the firsttime voters. During these years a number of studies have been undertaken to identify potential variables that influence the behavior of the electorate. The role of parents, friends, teachers, school programms, during adolescence and online social network, are ordered as key factors from recent research. For transition democracy countries, like Albania is, case studies regarding voting behavior have been limited. Therefore, given the fact, a study to understand the influence of explanatory variables in political behavior of first Albanian voters- was conducted. The study involved about 280 questionnaires and the survey was realized in a period of 4 days. The survey was conducted in six universities in Tirana, such as: European University of Tirana, Epoka University; Beder University; Tirana University; Faculty of Social Sciences; University of Medicine in Tirana. The data obtained from the study, confirmed the thesis that the political orientation of the first voters in suburban areas, affects more family than friends, while in metropolitan influences more group and online social networks than family.
\end{abstract}

Key words: Political behavior, Parents, Peers, Socialization, Online social networks, Political parties.

\section{INTRODUCTION}

Electoral behavior mostly on features that affect the final decision of the voters, which is very important for any political parties competing in the election process - is widely discussed in political debates. This is why many researchers have paid particular attention to analyze the first voters behavior. Research conducted in this area have primarily focused on identifying possible variables that affect political behavior of youth. In this context, among the possible variables that were attributed a significant measure of influence are: the role of parents, peers, teachers and different school programs (Beck \& Jennings, 1982; Martin 2012, Buckingham, D. (ed.) 2007; Marsh, D., O’Toole, T. \& Jones, S. 2007).

Not without reason, the most important role in the socialization process is attributed to the influence of family and specifically the influence of parents in shaping the political views among adolescents (Milburn and Conrad, 1998). Other researchers, like Jaime Settle or Robert Bond (2010) have extended this framework to include the effects of school facilities and civic education in school curricula, as well as experiences in adolescence as involvement in extracurricular activities and the use of online social networks. However, the role of the family 
in shaping political values remain crucial in the adolescence age, (Dawson and Prewitt 1969), the more that society teenager is very important for the individual, because it enables him emotional support in the delicate phase of separation from family and the construction of an independent model. Teenagers gradually internalize the values of their family, they try to choose friends and peers from the same stratification or social background of their families (Conger, 1973). They are so interested in politics and religious issues, as their families. According to Hartup (1983: 65) "...the gap between generations within a family is much dimmer than considered several decades ago. It is obvious the fact that the values and aspirations of younger generations and older ones within a family are very similar".

It should also be noted that parental levels, civic engagement and the socio-economic status of parents, influence the orientation of their child (Beck and Jennings 1982:94-108). Researchers as Torney-Purta, (2002) have explained that the family contributes to civic learning. Parents activity as parents membership in various organizations, news monitoring, news monitoring discussion, political knowledge, public communication or other services that they can do in the community, greatly influence the formation of their child (Mc Intosh, Hart and Youniss 2007: 495-499). Other researchers as Meirick \& Wackman (2004) have found in their studies positive reinforcement through politics and voting discussion in the family, also, parents taking children into the voting booth, can have a positive effect.

However, these data are valid until they are not taking into account the new changes that have occurred within the family. Many authors support the idea that a family is not static, but a dynamic environment that undergoes changes and transformations under the influence of processes that interact with it. "Family structural and functional changes are undergoing family changes as a social institution, along important social changes. The family has undergone major changes in the influence of the industrialization process" (Saraceno,1998:24). Perhaps, this means that the family is losing the impact that has had in shaping the political beliefs of their child as a result of the transformations that have occurred in global societies.

\section{Problem and Purpose}

The main purpose of this paper is to analyze the factors that influence the electoral behavior of Albanian first-voters and creating an analytical profile of electoral conduct. The study focuses on the review of indicators such as: family, children's relationship with parents, social groups, friends, relationship with them, partner, friends in online social networks - to analyze the factors that influence the electoral behavior. To conduct the study, as study unit, first and second -year students from public and not- public universities in Tirana, the capital of Albania - were selected.

\section{METHODOLOGY}

Methodologically, as a tool to provide empirical data, this study uses quantitative methods and random sampling. The sampling includes 280 questionnaires consisting of $42 \%$ females and $58 \%$ males while the university selection is random and not selected based on any specific criterion. The survey was conducted in universities such as: European University of Tirana, Epoka University; Beder University; Tirana University; Faculty of Social Sciences; University of Medicine in Tirana. Specifically, 36\% of respondents, study to the European University of Tirana, 22\% at Beder University, 14\% in Epoka University, 14\% at the University of Medicine and $14 \%$ in the Faculty of Social Sciences in Tirana. All these universities are located in Tirana.

The survey was conducted on a four-day period. Data from the survey found, disposed of in a table format in excel and were analyzed by using descriptive statistics. Data analysis was 
opposed by the questions raised and the main lines of the paper. The paper maintains the anonymity of the participants in the survey.

Basic assumption. Referring to the first-time voter behavior in Albania, was noticed that those who live in suburban areas tend to manifest more political convictions of parents versus peers than students who live in large urban areas that manifest more political convictions of peers than their parents.

Research question: What are the factors that affect voting behavior of students as first-voters in Albania and thus shape his profile?

Research sub-questions:

○ To what extent and manner the relationship parent - child affects the voting behavior of the student as first voters

$\circ$ To what extent and manner the social group affects the voting behavior of the student as first voters?

- To what extent and manner the online social networks affects the voting behavior of the student as first voters?

\section{RESULTS AND DISCUSSION}

\section{The parent- child relationship role in the political preferences of adolescent}

Given the data provided by the survey results that one of the variables that affects a considerable extent on the political behavior of students as first- voters is family. The charts below illustrate exactly that. Initially, students were asked if they were consulted by parents for their vote and the data in the chart below confirms that: $19 \%$ said they were consulting (very), 14\% confirmed that they were consulted (enough), 38\% were consulted (least), versus $29 \%$ who said they (were not consulted at all). These data show a high tendency of family influence. Take a look to chart no. 10

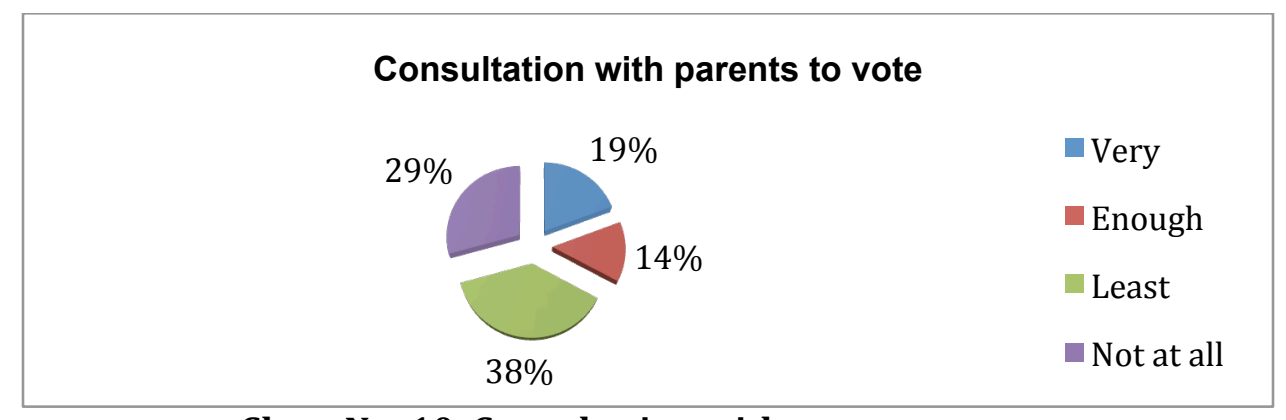

Chart No. 10. Consultation with parents to vote

There is an interesting fact. After being asked if their vote was similar to one parent, the respondents confirmed that: $48 \%$ of them confirmed that their vote was like the father votes, $40 \%$ confirmed that their vote was similar to the mother, while $12 \%$ of students stated that their votes did not fit with either parent. So, about $88 \%$ of respondents claimed that their votes manifest the voting behavior at least of one of the parents pushed us to think that we are still a strong gender division society.

Take a look to chart no. 11 on next page. 


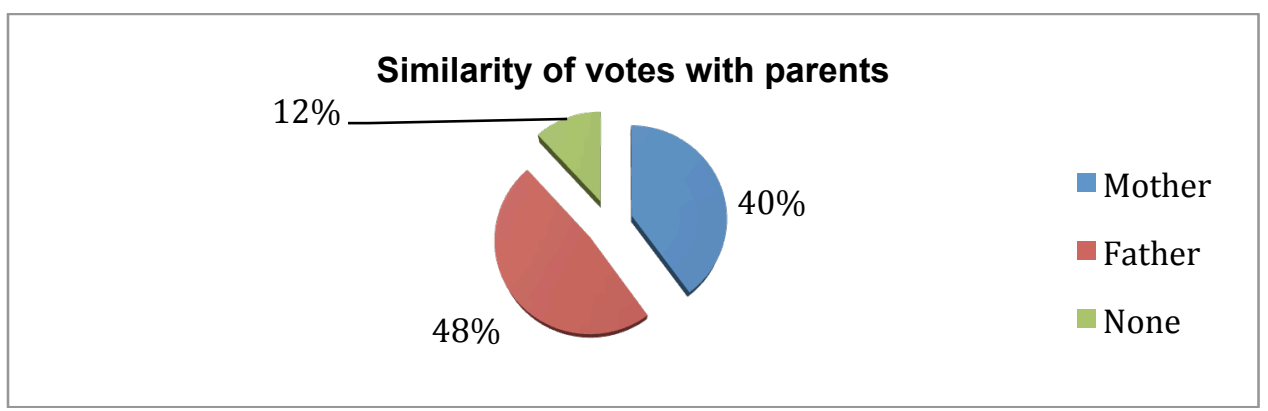

Chart No. 11. Similarity of votes with parents

In the framework of the variable regarding to parent- child relationship and the impact they would have on the political preferences of their children later, in the survey was predicted the question if teenager voters had gone at the same time with parents to vote. Their answers are presented in the following chart:

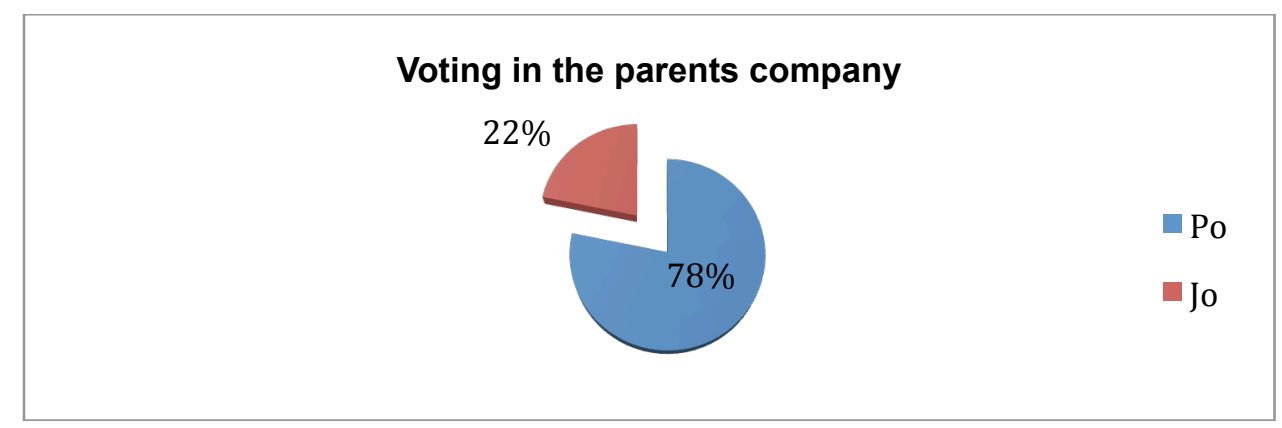

Chart No13. Voting in the parents company

From the above data affirm that $78 \%$ of respondents claim to have gone to vote at the same time with their parents and only $22 \%$ of them have gone with their friends. This data reinforce the idea that Albanian society considers the vote moment as a moment in which the family involvement is necessary and does not consider it as an individual process.

The social group role in shaping the political convictions to student as a first- voters in Albania for the general election in 2013

This section analyzes the relationship of the adolescent with the group through questions. They are asked if are consulted with their friends or partner about their vote before voting and the respondents stated at survey as follows: about $60 \%$ of the respondents chose "least" alternative, while $32 \%$ of them responded that "were not consulted" with their friends, compared with $2 \%$ who have claimed that are consulted "enough" and $6 \%$ "satisfactory". These data show a smaller effect of peers about the political behavior.

Take a look to chart no. 15

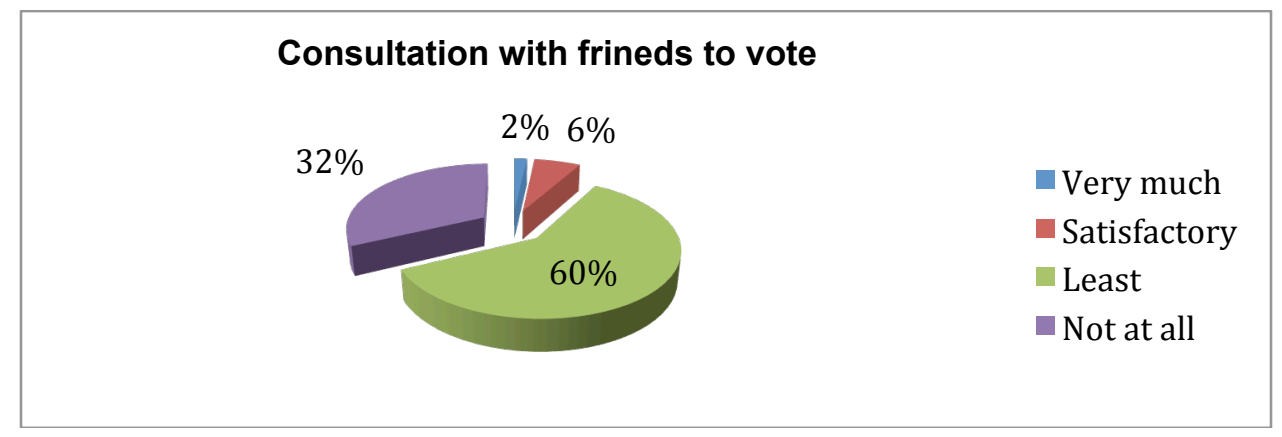

Chart No. 15. Consultation with friends to vote 
Despite the fact that a smaller number of them is consulted with their friends about the vote, in the focus of the study, the questionnaire had anticipated and another data for the category who claimed that were consulted with friends. The respondents answers shows that $80 \%$ of them claimed to have discussed the issue with school friends and only $20 \%$ of them claimed to have consulted their vote with childhood friends and none of them have not shared this conversation with neighborhood friends or online social networks friends. This data reveals that the school continues to be one of the most important institutions in the process socialization process for Albanian youth and in particularly for Albanian students. This data is demonstrated in the chart below:

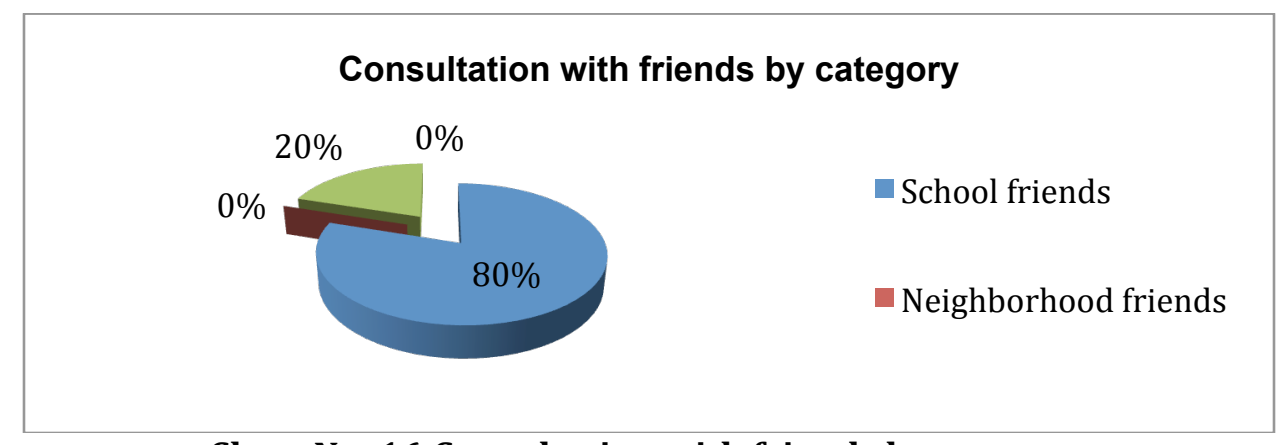

Chart No. 16 Consultation with friends by category

Another question that was involved in the survey was to find out the similarity vote of the respondents with their friends and if this vote was or not identical between them. The data show that $36 \%$ of respondents claim that their vote is identical with friends and peers. Of course, this information should not be interpreted strictly as a data that identifies friends influence on the political views, because we must remember that by processing the above data, we concluded that most of majority students involved in the survey were not consulted before with each other about their vote, but this data assume some common factors existence that may have influenced on their similar political perceptions.

Take a look to chart no. 17

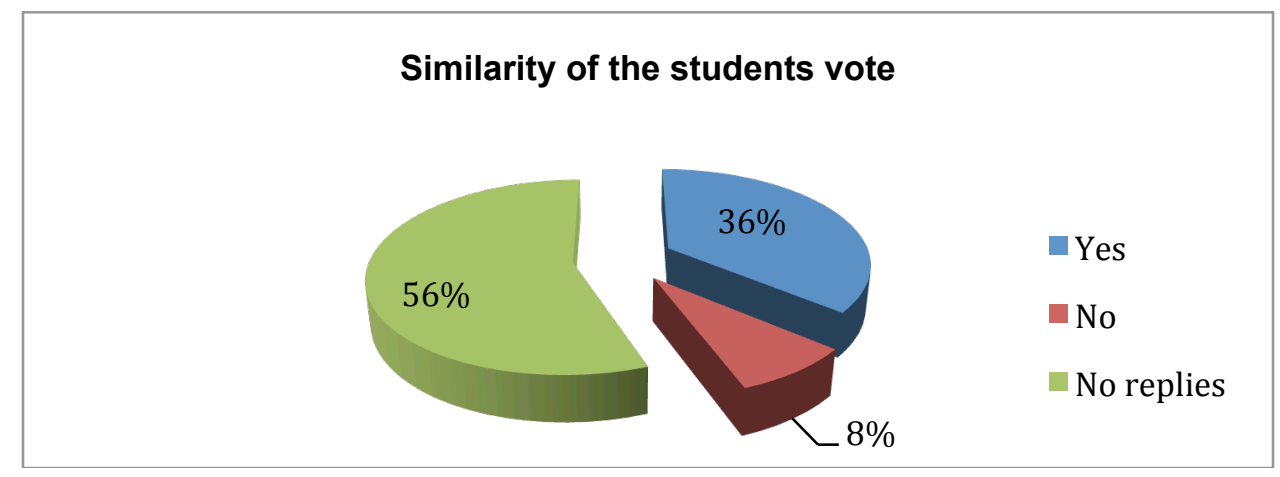

Chart No. 17 Similarity of the student vote

Another question anticipated on survey was related to the time of voting. Students involved in the survey were asked if they had gone to vote with their friends at the same time and postprocessing of the data was confirmed that $83 \%$ of respondents did not go to vote with their friends at the same time and only $17 \%$ were confirmed to have been in the company of their friends at the voting time. According to these data was confirmed again that most of the students surveyed have gone on their family company to vote, as it was found by processing the above data in the testing session of the independent variable regarding parent-child relation. 


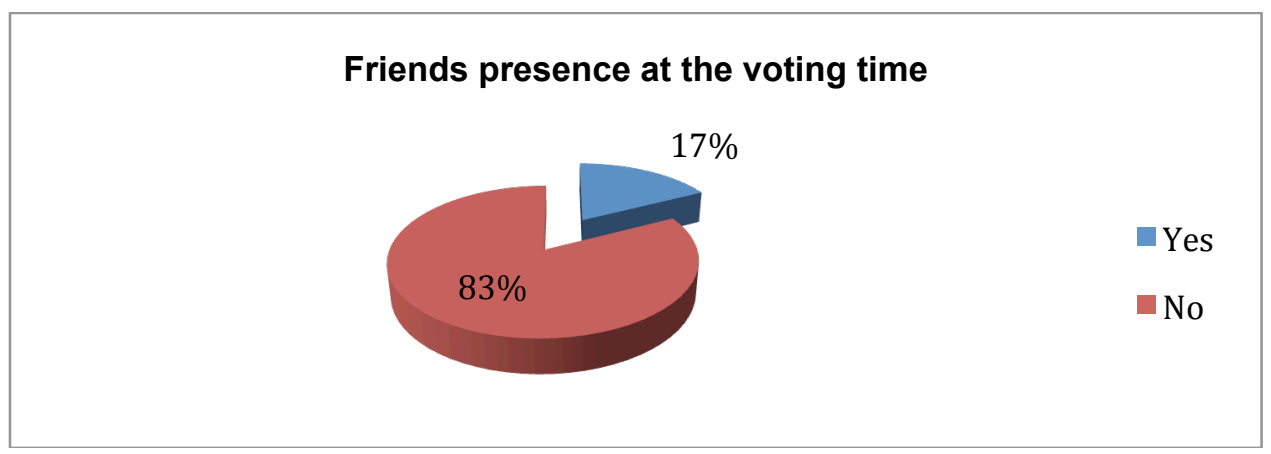

Chart No. 19 Friends presence at the voting time

Students that had gone in the same time with their friends to vote were asked if their vote were influenced by them. The data shows on the chart below confirm that $65 \%$ of respondents were not affected at all by their friends company, while $27 \%$ confirmed that were "enough" affected, $2 \%$ confirmed that were "very much" affected by their friends company and only $6 \%$ of them confirmed to have been "least" affected.

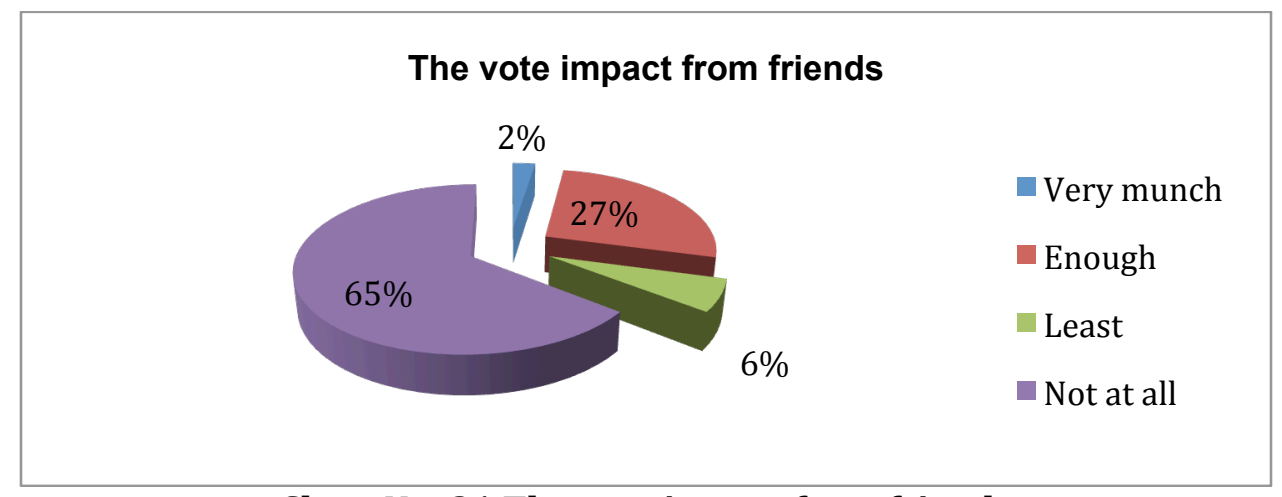

Chart No. 21.The vote impact from friends

\section{Students who live in large urban areas and those living in peripheral urban areas comparison}

The similarity of the student vote in the parliamentary elections of 2013 in relation to their parents was analyzed according to the divisions in the urbane area (metropolis) and peripheral urban areas. Comparative data show that the influence of variables: parents, peers, partner, is different. Specifically, in peripheral urban areas vote similarity with parents, respectively, 39\% with mother and 51\% with father, is higher than in urban metropolitan areas. According to the respondents, in metropolitan areas similarity vote with parents is lower than in suburban areas, respectively similarity vote is $32 \%$ with mother and $39 \%$ with father. However, despite the differences parents impact continue to be high. The difference are illustrate on Table no.1

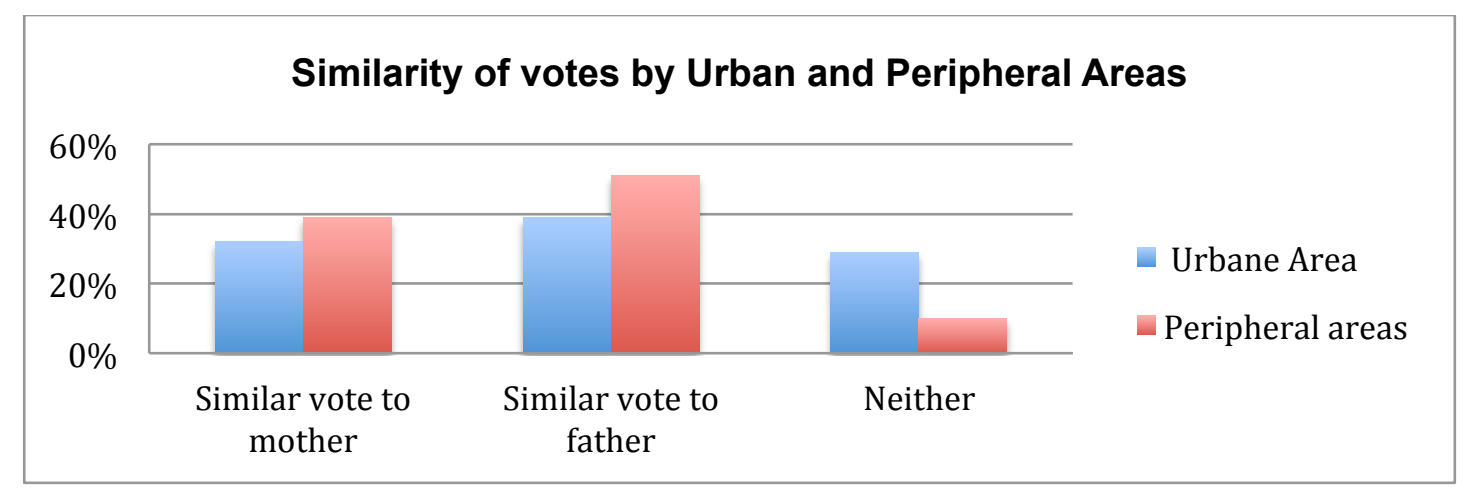

Table No.1 Similarity votes by area, Urban vs Peripheral Ares 
In terms of peer influence, again there is a difference between respondents who live in the metropolis and those that reside in peripheral urban areas. The data below show that the vote similarity with friends whether it is at low levels compared to the parents tends to be higher in metropolitan areas, 56\%, versus respondents coming from peripheral urban areas, respectively $37 \%$. Take a look to Table No. 2:

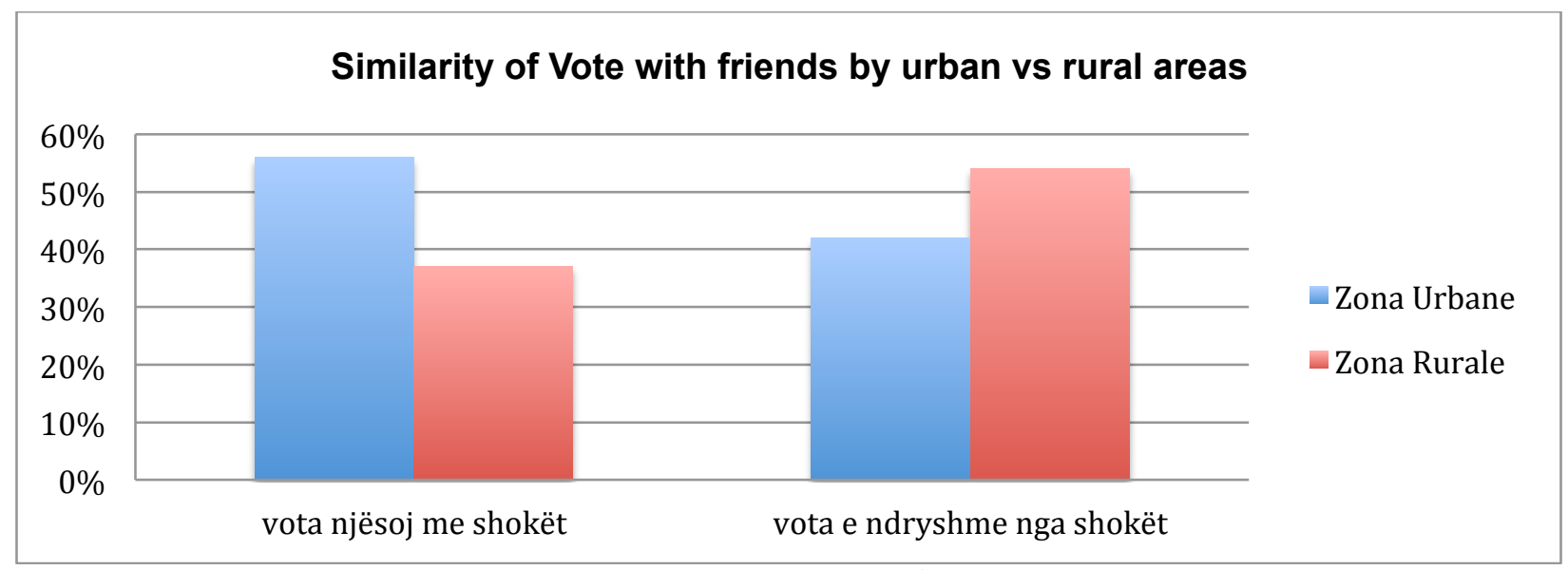

Table No.2 Vote similarity with friends by area

\section{CONCLUSION}

This study was focused on the features that influence the shaping of the first political perceptions to first Albanian voters. Initially was analyzed the family institution and more specifically parent-child role in creating political beliefs to adolescent, as the family is considered by many sociologists (Durkheim, Parson, Simmel, Habermas, Tonnies, etc.) as the most important institution in the socialization process.

Based on the processing and analysis of data from the field reached the conclusion that the Albanian student as first-voters, affected more in rural areas by parent-child relation, while in urban areas plays an important role the group, so friends. However, the influence of family members remains present and have a huge role. According to these findings, Albanian family continues to be very important in the political beliefs conveying to their children and why it has undergone several structure changes, as a result of migration or internal migration, diversity of information, increasing economic level etc.

In conclusion, the results of this study showed that the family continues to play an important role in shaping political persuasions to Albanian student as a first voters, mainly in the rural areas and less in urban areas, but at the same time, we should not deny the online social networks role, while in urban areas, the role of the family has waned a bit, given that social groups and online social networks, in this context play a significant role, while in rural areas the rate of use is relatively low.

\section{ACKNOWLEDGEMENTS}

For the realization of this study was necessary the cooperation of all students who filled the questionnaire, which gave us the data published above. Therefore, thank all those students who became part of this study.

\section{COMPETING INTERESTS}

Authors have declared that no competing interests exist. 


\section{AUTHORS' CONTRIBUTIONS}

Author Adela Danaj, designed the study, performed the statistical analysis, wrote the protocol, and wrote the first draft of the manuscript. Author Roland Lami, managed the analyses of the study and managed the literature searches. Both authors read and approved the final manuscript.

\section{REFERENCES}

Andolina, Molly W., Krista Jenkins, Cliff Zukin, and Scott Keeter. Habits from Home,Lessons from School: Influences on Youth Civic Development. PS: Political Science and Politics, 2003

Beck, Paul and M. Kent Jennings, Pathways to Participation, The American Political Science Review, 1982.

Beck, Paul and M. Kent Jennings. Pathways to Participation. The American Political Science Review, 1982

Becker, T., Slaton, D.Ch. The Future of Teledemocracy, London: PRAEGER, 2002

Buckingham, D. (ed.), Youth, Identity and Digital Media, MIT Press, Cambridge, 2007

Conger, J. J. "Adolescence and youth", Harper \& Row, New York, 1973

Couldry, N. Media, Shoqeria, Bota: Teoria sociale dhe praktika e medias digjitale, ISHM, Tiranw, Shqipwri, 2013. Albanian

Dawson, R. E. and K. Prewitt Political Socialization. Boston: Little Brown, 1969

Easton, D. and J. Dennis. Children and the Political System: Origins of Political Legitimacy, New York: McGraw-Hill, 1969

Hartup, W. W. The peer context in middle childhood In Collins, W. A. (Ed.). Development during middle childhood: The years from six to twelve. National Academy Press, Washington, D. C, 1983.

Jaime Settle Jaime, Bond Robert, The Effects of Social Integration within Adolescent Friendship Networks on Adult Political Behavior, University of California, San Diego

Marsh, D., O’Toole, T. \& Jones, S. Young People and Politics in the UK: Apathy or Alienation?, Palgrave, Basingstoke, 2007

McIntosh, H., D. Hart, and J. Youniss. The Influence of Family Political Discussion on Youth Civic Development: Which Parent Qualities Matter? July 2007

Meirick, P. and Wackman, D. Kids Voting and Political Knowledge: Narrowing Gaps, Informing Votes. Social Science Quarterly, 2004

Merelman. The Family and Political Socialization: Toward a Theory of Exchange. The Journal of Politics, 1980

Milburn, M. A \& Conrad, S. D. Persuasion and politics: The social psychology of public opinion. Pacific Grove, CA: Brooks-Cole/Wadsworth, 1995

Rahn, Wendy and John Transue. Social Trust and Value Change: The Decline of Social Capital in American Youth, 1976-1995. Political Psychology, 1998

Saha M, Adams ML, Nelson SC. Review of digit fusion in the mouse embryo. J Embryol Exp Morphol. 2009;49(3): (In press).

Saraceno, Chiara: Mutamenti della famiglia e politiche sociali in Italia, II Mulino, Bologna 1998.

Sherrod, L and C. Flanagan. Dimensions of Citizenship and Opportunities for Youth Development: The What, Why, When, Where, and Who of Citizenship Development. Applied Developmental Science, 2011 
Smith, Elizabeth. The Effects of Investments in the Social Capital of Youth on Political and Civic Behavior in Young Adulthood: A Longitudinal Analysis. Political Psychology, 1999

Stewart, A., \& Healy, J. M. Linking individual development and social changes. American Psychologist, 1989

Torney-Purta, J The school's role in developing civic engagement: A study of adolescents in twenty-eight countries. Applied Developmental Science, 2002

Young People and Politics: Political Engagement in the Anglo-American Democracies. Aaron J. Martin. Routledge. May 2012.

Youniss, James and Miranda Yates. Community Service and Social Responsibility in Yout, The University of Chicago Press, 1997

\section{Reference to a book:}

David G. Myers, Socialpsikologjia, Uegen, Tiranë, Shqipëri, 2003. Albanian

Denquin Jean- Marie. Hyrje në Shkencat Politik, UET Press, Tiranë, Shqipëri, 2001. Albanian

Dewey, John. Shkolla dhe shoqëria, Plejad, Tiranë, Shqipëri, 2003. Albanian 